\title{
Perbandingan (pH) Tanah Sawah Yang Tidak Menggunakan Dolomit Dengan Yang Menggunakan Dolomit Di Gampong Bukit Meutuah Kecamatan Langsa Timur
}

\author{
Sartika ${ }^{1}$, Rachmad Almi Putra ${ }^{1}$ \\ ${ }^{1,1}$ Jurusan Fisika Teknik, Universitas Samudra \\ *Co-Author: tika73022@gmail.com
}

\begin{abstract}
ABSTRAK
Telah dilakukan penelitian tentang perbandingan $\mathrm{pH}$ tanah yang tidak menggunakan dolomit dengan yang menggunakan dolomit di gampong Bukit Meutuah Kecamatan Langsa Timur yang bertujuan untuk mengetahui perbandingan $\mathrm{pH}$ tanah sawah yang tidak menggunakan dolomit dengan yang menggunakan dolomit. Pada penelitian ini didapatkan hasil perbandingan $\mathrm{pH}$ tanah sawah yaitu menggunakan dolomit memiliki $\mathrm{pH}$ yang jauh lebih tinggi dari $\mathrm{pH}$ tanah yang tidak meggunakan dolomit, $\mathrm{pH}$ tanah sawah yang menggunakan dolomit antara lain yaitu : 5,5, 6,0 dan 5,9. Sedangkan $\mathrm{pH}$ tanah yang tidak menggunakan dolomit memiliki $\mathrm{pH}$ yaitu 5,1, 5,3 serta 5,2. Dan kedua $\mathrm{pH}$ ini memiliki nilai rata-rata yakni pada tanah yang menggunakan dolomit diperoleh $\mathrm{pH}$ tanah rata-rata yakni 5,8 sedangkan $\mathrm{pH}$ rata-rata pada tanah yang tidak menggunakan dolomit yakni 5,2. Dari perbandingan kedua $\mathrm{pH}$ ini maka tanah yang baik untuk tanaman adalah tanah yang menggunakan dolomit karena nilai rata-rata pada tanah yang menggunakan dolomit mendekati $\mathrm{pH}$ netral, oleh sebab itu maka disarankan agar menggunakan dolomit sebelum pengolahan tanah.
\end{abstract}

Kata Kunci : Tanah, pH, Dolomit

\section{PENDAHULUAN}

Bidang pertanian khususnya dalam budidaya tanaman, keadaan tanah dan pengolahan tanah merupakan faktor penting yang dapat menentukan pertumbuhan tanaman. Tanah yang digunakan dalam bidang pertanian mempunyai tingkat kesuburan tanah yang berbeda-beda. Pengolahan tanah adalah faktor yang penting untuk menentukan pertumbuhan tanaman dan hasil tanaman yang akan dibudidayakan [1]. Tanah merupakan tempat tumbuh dan media penyediaan unsur hara untuk tanaman [2]. Pembentukan tanah berasal dari bahan-bahan yang berupa bahan mineral dan organik, serta udara. Dari proses pembentukan tanah, maka terbentuk juga perbedaan sifat kimia, fisis, biologi serta morfologi dari suatu tanah yang berbedabeda [3]. Tanah yang subur mampu menyediakan unsur hara yang mencukupi bagi tanaman, baik unsur makro maupun mikro [4]. Pemberian pupuk berfungsi untuk meningkatkan kesuburan tanah [5]. Pemupukan adalah salah satu tindakan dalam peningkatan unsur hara untuk tanah baik peningkatan secara langsung maupun tidak langsung, sehingga ketersediaan nutrisi untuk tanaman terpenuhi dengan baik. Unsur hara pada tanaman dapat berasal dari pupuk organik maupun pupuk anorganik [6]. Pemberian pupuk pada pengolahan tanah bertujuan untuk meningkatkan $\mathrm{pH}$ tanah [7].

Secara umum tanah di Indonesia banyak yang bersifat asam. Ultisol adalah jenis tanah yang memiliki $\mathrm{pH}$ asam. Derajat keasaman tanah berkisar antara 4-5 [8]. Pengapuran ialah salah satu cara yang dilakukan untuk memperbaiki tanah asam. Bahan yang digunakan untuk pengapuran diantaranya adalah dolomit [9]. Dolomit $\left[\mathrm{CaMg}\left(\mathrm{CO}_{3}\right)_{2}\right]$ adalah suatu material yang biasanya di berikan petani untuk mengurangi kemasaman tanah serta menambahkan unsur kalsium sebagai unsur hara pada tanaman. Kemudian pada dolomit juga terdapat unsur magnesium sebagai unsur hara pokok yang diberikan pada tanah yang miskin magnesium [10]. Unsur hara magnesium yang terkandung pada dolomit adalah unsur hara makro yang berperan untuk proses fotosintesis[11]. Kandungan unsur hara pada dolomit yaitu kalsium karbonat $\left(\mathrm{CaCO}_{3}\right) \%$, magnesium karbonat $\left(\mathrm{MgCO}_{3}\right) \%, \mathrm{CaO}(30,4 \%), \mathrm{CO}_{2}(47,7 \%), \mathrm{MgO}(21,9 \%)$ dan sedikit senyawa besi, mangan, silica, serta senyawa lain $(0,05 \%)[13]$.

\section{METODE PENELITIAN}

Adapun waktu pelaksaan penelitian ini dilakukan selama 3 minggu, dimulai pada tanggal 13 Januari s/d 05 Februari 2021. Setiap hari senin hingga jum'at jam kerja dilakukan dari pukul 08:00-17:00 WIB. Tempat Pelaksaannya adalah di Kantor BPP-K (Balai Penyuluhan Pertanian dan Kehutanan ) Di Langsa Timur.

Pada penelitian ini dilakukan tentang perbandingan $\mathrm{pH}$ tanah sawah yag tidak menggunakan dolomit dengan yang menggunakan dolomit. Pengambilan data dilakukan dengan menggunakan alat yaitu Takemura DM-5 atau biasa disebut dengan pH Tancap. Cara penggunaan Takemura DM-5 adalah : 1) Bersihkan ujung alat dengan kain/tisu kering, 2) Tancapkan alat pada tanah yang ingin diukur tingkat keasamannya (kadalaman tancapan sesuai dengan batas yang ada pada alat tersebut), 3) Kemudian tekan tombol warna putih, 4) Tunggu sampai jarum indikator berhenti bergerak, 5) Baca $\mathrm{pH}$ tanah yang ditunjukkan jarum tersebut. 
Pengambilan data dari beberapa sawah petani di Gampong Bukit Meutuah dengan cara : 1). Mengetahui Luas sawah di Buket Meutuah diperkirakan $800 \mathrm{~m}^{2}$ dengan dosis dolomit 166,4 kg persawah. 2) Pengukuran $\mathrm{pH}$ yang pertama pada area sawah yang tidak menggunakan dolomit, dilakukan pengukuran sebanyak 3 titik. 3) Pengukuran $\mathrm{pH}$ dilakukan dengan penancapan Takemura DM-5/pH Tancap dengan kedalaman $7 \mathrm{~cm}$, kemudian di tunggu sampai 5 menit,lalu jarum akan berhenti bergerak dan menunjukkan nilai $\mathrm{pH}$ nya. 4) Titik yang ke-1 dengan $\mathrm{pH} 5,1$, titik ke-2 dengan $\mathrm{pH} 5,3$ dan $\mathrm{pH}$ yang ke-3 adalah 5,2. 5) Selanjutnya pengukuran pada area tanah sawah yang menggunakan dolomit. 6) Titik ke-1 diperoleh $\mathrm{pH}$ 5,5 , titik ke-2 dengan pH 6,0 dan titik yang ke-3 adalah 5,9.

\section{HASIL DAN PEMBAHASAN}

Data yang akan di analisis berupa Pengukuran pH Tanah yang tidak Menggunakan Dolomit, didapatkan data hasil pengukuran tersebut pada Tabel 3.1.

3.1 Hasil Pengukuran pH Tanah Yang Tidak Menggunakan Dolomit

\begin{tabular}{|c|c|c|c|c|}
\hline no & Perlakuan & Luas $\left(\mathrm{m}^{2}\right)$ & Dosis kapur dolomit $(\mathrm{kg})$ & $\mathrm{pH}$ \\
\hline 1 & T1 & 800 & - & 5,1 \\
\hline 2 & T2 & 800 & - & 5,3 \\
\hline 3 & T3 & 800 & - & 5,2 \\
\hline \multicolumn{2}{|r|}{} & 800 & & 5,2 \\
\hline
\end{tabular}

Dari tabel diatas menjelaskan tentang pengukuran $\mathrm{pH}$ pada tanah sawah yang tidak menggunakan dolomit.

Tabel 3.1 merupakan pengukuran $\mathrm{pH}$ tanah sawah yang tidak menggunakan kapur dolomit di desa Buket Meutuah. Dari hasil pengukuran yang dilakukan di peroleh nilai rata-rata $\mathrm{pH}$ adalah 5,2 dan $\mathrm{pH}$ ini termasuk kedalam tanah asam. Tanah masam umumnya mempunyai pH kurang dari 5,5 (Wijanarko \& Taufiq, 2004). Dimana tanah asam akan menyebabkan tanaman kurang baik dalam menghasilkan produksi yang banyak, karena ini bisa menjadi kendala pada pertumbuhan tanaman tersebut. Tanah asam memiliki unsur hara yang sedikit, sehingga tanaman kurang mendapatkan unsur hara yang diperlukan.

Data yang akan di analisis berupa Pengukuran pH Tanah yang Menggunakan Dolomit, didapatkan data hasil pengukuran tersebut pada Tabel 3.2.

3.2 Hasil Pengukuran pH Tanah Yang Menggunakan Dolomit

\begin{tabular}{|c|c|c|c|c|}
\hline No & perlakuan & Luas $\left(\mathrm{m}^{2}\right)$ & Dosis kapur dolomit $(\mathrm{kg})$ & $\mathrm{pH}$ \\
\hline 1 & $\mathrm{~T} 1$ & 800 & 166,4 & 5,5 \\
\hline 2 & $\mathrm{~T} 2$ & 800 & 166,4 & 6,0 \\
\hline 3 & $\mathrm{~T} 3$ & 800 & 166,4 & 5,9 \\
\hline \multicolumn{2}{|r|}{100,4} \\
\hline
\end{tabular}

Dari tabel diatas menujukkan tentang pengukuran $\mathrm{pH}$ tanah sawah yang menggunakan dolomit.

Berdasarkan tabel 3.2 dapat di simpulkan bahwa nilai rata-rata yang diperoleh dari pengukuran $\mathrm{pH}$ pada sawah yang menggunakan dolomit adalah 5,8. $\mathrm{pH}$ ini dikatakan bagus bagi tanaman, $\mathrm{pH}$ yang baik akan mempengaruhi hasil produksi yang dihasilkan tanaman tersebut. Tabel 3.2 merupakan pengukuran $\mathrm{pH}$ tanah sawah yang menggunakan dolomit di Gampong Buket Meutuah. Dari pengukuran yang telah dilakukan, maka didapatkan pH seperti yang tertera pada tabel 3.2.

Data yang akan di analisis berupa Perbandingan pengukuran $\mathrm{pH}$ tanah yang tidak menggunakan dolomit dengan tanah yang menggunakan dolomit, maka didapatkan data perbandingan tersebut pada Tabel 3.3.

3.3 Perbandingan pH Tanah Sawah Yang Tidak Menggunakan Dolomit Dengan Yang Menggunakan Dolomit

\begin{tabular}{|c|c|}
\hline $\begin{array}{c}\text { Tanah Yang Tidak Menggunakan } \\
\text { Dolomit }\end{array}$ & $\begin{array}{c}\text { Tanah Sawah Yang Menggunakan } \\
\text { Dolomit }\end{array}$ \\
\hline 5,2 & 5,8 \\
\hline
\end{tabular}

Dari tabel diatas menujukkan tentang perbandingan $\mathrm{pH}$ tanah yang tidak menggunakan dolomit dengan tanah yang menggunakan dolomit.

Tabel 3.3 merupakan analisis perbandingan dari rata-rata $\mathrm{pH}$ antara tanah sawah yang tidak menggunakan dolomit dengan yang menggunakan dolomit. Dari nilai rata-rata untuk sawah yang tidak menggunakan dolomit didapatkan nilai 5,2 dan masih tergolong kedalam $\mathrm{pH}$ asam. 
Jika tanah memiliki pH asam, maka pertumbuhan tanaman kurang bagus, sedangkan pada rata-rata nilai pengukuran $\mathrm{pH}$ tanah sawah yang menggunakan dolomit didapatkan rata-rata 5,8. $\mathrm{pH}$ 5,8 didalam pertanian dapat dikatakan bahwa tanah tersebut merupakan tanah yang yang sudah mendekati tanah subur, dimana tanah yang subur dapat menghasilkan produksi yang maksimal. Jadi jelas terlihat perbedaan $\mathrm{pH}$ pada tanah yang menggunakan kapur dolomit dengan yang tidak. Hasilnya penggunaan dolomit untuk tanah dapat meningkatkan kesuburan pada tanah sehingga meningkatkan pula hasil produksi pada tanaman tersebut.

\section{KESIMPULAN}

4.1 kesimpulan yang diperoleh dari penelitian ini adalah : Hasil yang diperoleh pada perbandingan yaitu tanah yang menggunakan dolomit lebih unggul yaitu 5,8 daripada tanah yang tidak menggunakan dolomit yaitu 5,2. Kemudian hasil perbandingan antara $\mathrm{pH}$ tanah sawah yang menggunakan dolomit dengan yang tidak menggunakan dolomit tentu sangat jauh berbeda, $\mathrm{pH}$ yang baik untuk tanaman adalah 6,0 dan $\mathrm{pH}$ ini merupakan hasil penambahan dolomit pada tanah untuk mengurangi keasaman dan Penggunaan dolomit pada tanah dapat meningkatkan kesuburan pada tanah karena ketersediaan unsur hara yang memadai bagi tanaman.

\section{UCAPAN TERIMA KASIH}

Saya ucapkan terimakasih kepada bapak dan ibu dan juga teman-teman yang telah membantu saya dalam pelaksanaan penelitian ini.

\section{DAFTAR PUSTAKA}

[1] Tri Wahyuni, 2020. (2020). Evaluasi Status Kesuburan Tanah Sawah Desa Tebing Kaning Kabupaten Bengkulu

[2] Rossi, 2008. (2010). Analisis Tanah Sebagai Indikator Tingkat Kesuburan Lahan Budidaya Pertanian Di Kota Semarang. 2008, 59-64.

[3] Nurul, mas’ud waqiah. (2013). 済無No Title No Title. Persepsi Masyarakat Terhadap Perawatan Ortodontik Yang Dilakukan Oleh Pihak Non Profesional, 53(9), 1689-1699.

[4] Rossi, 2008. (2010). Analisis Tanah Sebagai Indikator Tingkat Kesuburan Lahan Budidaya Pertanian Di Kota Semarang. 2008, 59-64.

[5] Suarjana, 2016. (2016). Kajian Status Kesuburan Tanah Sawah Untuk Menentukan Anjuran Pemupukan Berimbang Spesifik Lokasi Tanaman Padi Di Kecamatan Manggis. E-Jurnal Agroekoteknologi Tropika (Journal of Tropical Agroecotechnology), 4(4), 314-323.

[6] Sera, G., Sitompul, S., Yetti, H., Agroteknologi, J., Pertanian, F., Riau, U., Widya, K. B., \& Baru, S. (2017). Pengaruh Pemberian Pupuk Kandang dan KCl Terhadap Pertumbuhan dan Produksi Tanaman Bawang Merah ( Allium ascalonicum L.) The Effect of Manure and KCl Fertilizer on Growth and Productivity of Shallot (Allium ascalonicum L. ). 4(1), 1-12.

[7] Hong Lawing, Y. (2018). Pengaruh Pemberian Kapur Dolomit Terhadap Pertumbuhan Bibit Gaharu Pada Lahan Pasca Tambang PT TANITO HARUM. Jurnal Geologi Pertambangan, 1(23), 31-42.

[8] Wasito, 2017. (2017). Indonesian Journal of Chemical Science Test Strip Pengukur pH dari Bahan Alam yang Diimmobilisasi dalam Kertas Selulosa. 6(3), 3-9.

[9] Rosmaiti, I., MP, I. S., \& Fauzi, A. (2017). Pengaruh Kehalusan Kapur Terhadap Pertumbuhan Dan Produksi Kedelai (Glycine Max (L) Merrill) Pada Tingkat Kemasaman Tanah Yang Berbeda. Jurnal Penelitian, 4(1), $23-34$.

[10] Kurniasih, K., Jubaedah, D., \& Syaifudin, M. (2019). Pemanfaatan Kapur Dolomit [Camg(Co3)2] Untuk Meningkatkan Ph Air Rawa Lebak Pada Pemeliharaan Benih Ikan Patin Siam (Pangasius Hypophthalmus). Jurnal Akuakultur Rawa Indonesia, 7(1), 1-12. https://doi.org/10.36706/jari.v7i1.9018

[11] Masefa, L., \& Periadnadi, N. (2016). Pengaruh Kapur dan Dolomit Terhadap Pertumbuhan Miselium dan Produksi Jamur Tiram Cokelat ( Pleurotus cystidiosus O. K Miller ) The Effect of Calcite and Dolomite to The Mycelium Growth and Production of Brown Oyster Mushroom ( Pleurotus cystidiosus O . Jurnal of Natural Science, 5(1), 1120.

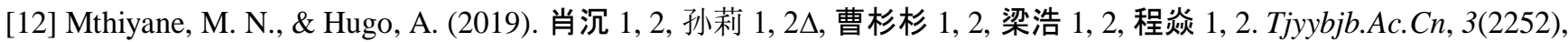
58-66. http://www.tjyybjb.ac.cn/CN/article/downloadArticleFile.do?attachType=PDF\&id=9987 